Journal of Engineering and Applied Sciences 15 (6): 1251-1256, 2020

ISSN: 1816-949X

(C) Medwell Journals, 2020

\title{
The Background of Souvenirs in Luang Prabang
}

\author{
${ }^{1}$ Krid Wilaiolarn, ${ }^{1}$ Kittisan Sriruksa and ${ }^{2}$ Teerayut Pengchai \\ ${ }^{1}$ Faculty of Fine and Applied Arts, Khon Kaen University, 123 Mittraphap Road, \\ Nai Mueang Sub-District, Mueang District, Khon Kaen Province, Thailand \\ ${ }^{2}$ Faculty of Humanities and Social Sciences, Udon Thani Rajabhat University, \\ Udon Thani Province, Thailand
}

\begin{abstract}
The article on examine the background of souvenirs in Luang Prabang was the objectives of studying the background of the souvenirs in Luang Prabang. This article is part of the research on the factors that affects the process of souvenir making in Luang Prabang. The tools used in this research were field surveys, participatory observation, structured interviews nad group discussions with 50 villagers: 10 experts, 30 practitioners and 10 other people who are related to the issue. The results from the study showed that the background of souvenirs in Luang Prabang had its development on the meaning of the souvenirs according to four different eras: pre-Lan Xang kingdom era, Lan Xang kingdom era, post-Lan Xang kingdom era and World Heritage era. The changes that had happened were linear changes starting from Luang Prabang city in the past, when the household appliances and handicrafts became part of the tributes, gifts, presents, royal appliances nad eventually became part of the souvenirs that can be seen in Luang Prabang today.
\end{abstract}

Key words: Souvenirs, background of souvenirs, Luang Prabang city, Lan Xang kingdom, observation, World Heritage era

\section{INTRODUCTION}

From the past to the present, "souvenirs" have always had an important role in the livelihood of people. This fact can be observed from the souvenirs that were given to a person when they were born to their last day. When a person passes away, souvenirs were also given out at the funeral (Silrattana, 2001). Currently, many tourists are interested in purchasing souvenirs which push the souvenirs to become important products and businesses that help bring in much money to the country, especially in Lao PDR.

In Lao People's Democratic Republic or Lao PDR, the government had set the goal that by 2020, the country will no longer be an underdeveloped country or a poor country but becomes one of the leading countries in the region (Bodhisan, 2015). By becoming part of the ASEAN Economic Community in 2015, tourism in Laos has been expanding, especially in Luang Prabang, a place that is well-known for tourists around the world. The fact that the city was registered as a World Heritage site in 1995 changed the way of life of the people. The livelihood, the traditions and norms and the culture were managed under the policies aimed at tourism. However, the things that can still maintain the identity of this World Heritage city are the souvenirs.

The meaning of the word "souvenirs" or ของที่ระลกึ" (in Thai), the word " ของ" means objects or things (Office of the Royal Society in 2003) and the word “ ทรีะลก๋” (in Thai) means to remind of something or someone (Silrattana, 2001). Therefore, the two words, when put together means objects that reminds a person of someone or something. This word has the same meaning of the word “ ของที่ระนก้ (in Lao) which means things that remind or gets a person to think of something or someone (Kasetsart University, 2000). The word “ เค่ื่อืง ” (in Lao) means things that were made by people for different kinds of usage which is also used as a prefix for several objects. This goes in line with what stated that for souvenirs ( ของที่ระนกึ), Lao people in general called “ ของตอ้น or " เครื่ องตอ้น ". People in the royal palace in some eras also used the word “ เครื่อืงบนันากาน" (in Lao) or “เคร่อืงบรรณาการ” (in Thai) which means the things that were sent to a person out of respect or friendship. This goes in line with what Bodhisan (2015) said in his research that both Lao and Thai people used to use the same word for "souvenir". However, the word was later changed to

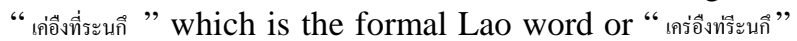
which has the same meaning as "ของที่ระลกึ" which means things that are used for welcoming guests.

It is very difficult to research the background of the souvenirs, since, the act of giving souvenirs were never considering the things that were created by human and the act of giving and sharing as an act that caused people to be "reminded" or to "think of" certain people or moments, then it can be assumed that "souvenirs have always 
existed, since, the first human being was born on Earth” (Silrattana, 2001). Souvenirs in the past came from both the norms, the tradition nad the way of life. In Lao history, there were mentions of "tributes" which Masuhara (2003) talked about the pre-modern era or since, the year 1843 that the relationship of Lao and China was through, the tribute system. In the past, the tributes from the Lan Xang kingdom which included elephant tusks, rhino horns, gold or silver wares. This relationship had an essential role in creating the base for the economic growth of the Lan Xang kingdom. Later on Luang Prabang became the center of the trade. The handicrafts that were important during the time were silverware, basketry, textile both as clothing and one of the significant tributes for the palace which were sometimes used in place of money (Weeravong, 1997).

From the time of king Fa Ngum, the king who established the Lan Xang kingdom who introduced Lankavamsa as well as bringing in "Phra Prang" into Xiang Dong Xiang Thong city before changing the name of "Luang Prabang” during the time of king Vixunharat. Later on, from the relationship and the influence from Lanna kingdom during the time of king Xaysettha, the capital was moved to Vientiane until the time of king Souriyaving which is the golden period of Buddhism, before the kingdom was split into three and fell under the rule of Siam (Srisamang, 2002). The kingdom, later on, fell under the influence of the French during the time of king Oun Kham until the kingdom of Lao declared its independence in the time if king Sisavangvong and the system changed under the ruling of king Sisavangvattana. The monarchy was abolished and another system, the socialist system was put in place, led by the Lao people's revolution party and the name of the country was changed to Lao PDR until the present time (Mettarikanon, 2012). It can be seen that in Luang Prabang, there had been changes in the society and culture after having gone through some major events throughout the eras. The current souvenirs in Luang Prabang consist of silverware, textiles, carved wood, mulberry paper products, basketry nad paintings. These souvenirs reflect the characteristics of the society and culture, the norms and the tradition as a Buddhist city and the former capital of the Lan Xang kingdom.

However, although, Luang Prabang was the former capital of the great Lan Xang kingdom with an extensive history, art and culture, there had been no study on the souvenirs from different eras. The studies that were found were only those on handicrafts and arts within Luang Prabang city. Souvenirs are another kind of items that reflect the norms and culture and the way of life of the people in Luang Prabang. They also reflect the skills embedded within each of the items. These are the things that will fade away one day without the passing on of the knowledge. Besides, products are being imported from other countries being sold alongside the local souvenirs and the tourists themselves might not pay attention to where the souvenirs were made. This can potentially affect the quality of the souvenirs and the memory of the people on Luang Prabang city.

Research objectives: To study the background of souvenirs in Luang Prabang city.

Definition of terms: Souvenirs mean the different items in Luang Prabang which include silverware, textiles, carved wood, mulberry paper products, basketry and paintings.

Background means the souvenirs in Luang Prabang according to the following eras: pre-Lan Xang kingdom era, Lang Xang kingdom era, post-Lan Xang kingdom era nad World Heritage era.

\section{Scope of the study}

Scope of the content: The content within the article aims at studying the background of souvenirs in Luang Prabang Scope of the area of study: souvenir shops in Luang Prabang city in Laos PDR.

\section{MATERIALS AND METHODS}

Population and target group: Purposive sampling was used by the researchers to determine the target population which consist of the following knowledgeable people who have the understanding and are directly involved with souvenirs as well as being experts on souvenirs in Luang Prabang: such as Lao historian and cultural experts, head and vice head of the Ministry of Information, Culture and Tourism, the knowledgeable people within the Luang Prabang World Heritage office, the leaders of the districts and the elders in Luang Prabang in order to learn about the background of the souvenirs. In addition, the population also includes the practitioners such as the producers or people related to the production and the selling of the souvenirs in Luang Prabang. The last group of the population was the consumers or the tourists who buy the souvenirs.

Research tools: The research tools consist of field survey, non-participatory observation, non-structured and structured interviews and group discussions.

Data collection: There are two kinds of data collection: collecting primary data or field data by doing field surveys in Luang Prabang to look at both the physical geology, the social and cultural aspects and the way of life. Collecting secondary data by related literature and research. 
Data analysis: The researcher had conducted data verification and analysis according to the following objectives:

- Triangulation: verifying the accuracy of the data by considering three sources: time, location and people

- Primary analysis: categorizing the different types of data according to their appropriacy

- Analysis of the data that are both based on theories and not based on any theory

- Comparisons of the analyzed data to investigate the relationship between the data

Presenting the result from data analysis: This research applied the qualitative research method to present the result through descriptive analysis.

\section{RESULTS AND DISCUSSION}

The result from the study on the background of souvenirs in Luang Prabang can be categorized into four different eras: Pre-Lan Xang kingdom era, during the Lan Xang kingdom era, Post-Land Xang kingdom era nad the World Heritage era.

Pre-Lan Xang kingdom era it is not clear up until now when the souvenirs were made prior to the establishment of Luang Prabang city due to the fact that the city itself was in the process of being built. Therefore, the souvenirs during this period were food, hunting equipment, tools that were made from natural materials which will be given out to people within the same group. It is believed that people who were living there before Luang Prabang was established was already giving hunting equipment or daily tools as souvenirs or tokens of remembrance.

During the Lan Xang kingdom era king Fa Ngum, the ruler of Lan Xang kingdom started the process of establishing the kingdom after his return to Xiang Dong Xiang Thong city while bringing in "Prabang" into the kingdom. Later, king Xaysettha invited artisans from Lanna kingdom in which had caused the arts during this period to be influenced by Lanna arts. Eventually, under the rule of Siam until the end of the Lan Xang kingdom in the year 1893, the art was influenced by Siam.

The souvenirs during these periods of times were handicrafts, tools and decorations for the daily lives of the people that received the influence from the Lan Xang kingdom such as basketry, carved wood, paintings, mulberry paper products and especially textiles and silverware. These were also part of the tributes amongst the ruling class, since, there were conflicts between the ruling class and other classes within the society on the issue of expanding the territory. The souvenirs were therefore meant to remind others of the givers. The kingdom was also under the rule of the Burmese for a short period. After the Lan Xang kingdom split apart, the three kingdoms came under the ruling of Siam for 114 years.

As mentioned above, the phenomenon in this era shows the changes in the meaning of souvenirs according to the changing eras, starting from things that were made within the households for sharing and exchanging to the production for sustaining livelihood for trading as well as for using as tributes before becoming the current products of today. Different names were also used for different eras according to the social and cultural changes. Therefore, from the conclusion of the reliable results, the souvenirs were referred to under different names. Nevertheless, most of the souvenirs consist of local handicrafts, tributes and gifts. From the summary of the documents and form the experts who are Lao, the words that were used were the different words that have close meaning to souvenirs. However, the differences amongst the different objects were the forms, the materials, the productions, the usages, the beauty as well as the creation process due to the different factors. It is difficult to find any records or pieces of evidence on the detail of the different souvenirs on when they were produced because in 1872, Luang Prabang was attacked by the Chinese bandits who apart from taking the valuables, also destroyed temples and homes. The evidence about the souvenirs might also be destroyed during this time. This goes in line with the what Fox and Stuart wrote saying that a mixed army consisting of Chinese bandits and highland Tai warriors raided and burned down Luang Prabang towards the end of king Oun Kham rule.

Post-Lan Xang kingdom: The souvenirs in Luang Prabang in the Post-Lan Xang kingdom era can be traced back from when the kingdom was under the ruling of France on the year 1893 and also during the kingdom of Lao, the revolution on 1975, until the new thinking era. At the time, Laos had taken in technologies from outside societies and cultures. There started to be important memos from famous travelers such as Mr. Gerrit Van Wusthoff until the French colonization period or until the Lan Xang kingdom fell under the rule of Siam and later on France until the year 1954.

World Heritage era: The beginning of the socialist system. During this time, there had been changes in the traditional Lao society and culture initiated by the power of the new government to eradicate the beautiful traditional norms and traditions. This had caused the way of life of the people in Luang Prabang to change. It is also the time when the global trend was moving towards globalization and Luang Prabang was declared as a World Heritage site, since, the year 1995 up until the present time. From the background of the souvenirs in Luang Prabang, it can be seen from the overall picture how 
that during pre-Lan Xang era, the Lan Xang era and the post-Lan Xang era, the souvenirs in Luang Prabang have always been the products produced by Lao people. Those souvenirs present beautiful traditions and livelihood. The handicrafts that has exist for a long time had been improved and developed in its forms as well as the skills from the makers which can be seen in the 17th century through the ancient artifacts and the records by the Foreigners that were in the country at the time such as metal handicrafts, textiles and other jewelry. However, the conclusion from the data suggests that the souvenirs during this time were silverware, basketry, textiles, carved wood, mulberry paper products and paintings.

Discussion on the background of the souvenirs in Luang Prabang: Souvenirs in Luang Prabang in the former eras had different names according to each era, starting from the connection with the society outside, since, the pre-Lan Xang kingdom era. The open-society was welcoming to the social and cultural changes than the close-society. From the relationship under the tribute system with China, since, the Yuan Dynasty and again during the 15th century with the Ming Dynasty, textiles were valuable products such as metallic fiber, textile with flowery patterm, thing fabric, flannel, silk and money. During the Lan Xang kingdom era, the meaning of the souvenirs during the period before Luang Prabang was established was all aimed at being tributes; such as elephant tusks, rhino's horns, gold and silverware nad local products. The relationship during the time was a non-political role relationship which contributes to the growth in the economic base of the kingdom. It was a wise move to continuously encourage economic growth, since, it allowed the society of Luang Prabang which had easier connect with other societies it is early years to encounter higher changing rate. This mostly happens to cities that were considered as the main hub for both land and water transportation which was how Luang Prabang was. This goes in line with what Masuhara (2003) said that due to the fact that the city was the center for trades and communication, the economy of Lan Xang was blooming and the arts and culture aspect of the city was at its peak during the Lan Xang kingdom under the rule of King Souriyavoungsa. The changes that happened during that period was linear. The academic that proposed this theory was Auguste Comte who talked about the changes from the lower civilized society to a higher one. Similar to Srisontisuk (2001) who stated that the changes that happened according to the era were not leaped changes but the changes with a slow process because of the characteristics of Lao people in being simple and not rushing things.

The reasons for the changes in the souvenirs started from cultural change. The values and objectives were more towards exchanging, giving as gifts or tributes, rather than being artifacts like today. These practices were carried on by the local people for generations. After the city started to connect with other cities with a different culture through trades they began to imitate and adopt the new things to the things that are already in existence for instance, the silverware of Luang Prabang. Those silver wares which were only used by the aristocrats and royal families to display their royalties were later on used in religious ceremonies such as some of the king's items with unique patterns compared to those of the commoners were now sold to everyone who wants to buy them. The patterns that were specifically used only for the king had changed their meaning. As for textiles, some of the patterns were only used for people within the palace or the clothing of the king which include gold linings are now being used to make clothes for tourism. The context of the textiles was changed from making clothing that was used for daily work for the Tai Lue villagers or the kind of cloth that women in every household need to weave for religious ceremonies to cloths with additional patterns which became part of the products to be sold. Basketry products that were used in the daily lives of the people were replicated and now used as household decorations or souvenirs. Carved wooden Buddha images that were used for religious purposes were also replicated as the products to attract tourists. Mulberry paper products that were used as wrappings items, making umbrellas, used as a notepad for monks or making lanterns are currently products for sale similar to those of the Nothern Thailand.

New things that were created and developed had changes the cultural ways of the people in Luang Prabang from the past to the present. The wars and the changes in politics and the government had led to many changes. Handicrafts products that were created for daily usages are now being created for decoration. The people who buy these products changed from the local people in Luang Prabang to Foreign tourists. The forms of the souvenirs became modern while still trying to maintain the traditional way of making which goes in line with the research by UNESCO (2004) which was made into a book titled IMPACT: the effects of tourism on culture in Luang Prabang, Lao PDR. This research by UNESCO affirms the fact that the current situation in Luang Prabangis drawing interest from others due to its status as a World's Heritage cite. Due to the physical surrounding, nature and the weather, the changes happened slowly while people are still able to maintain their traditional way of life.

As society changes along with the development of people's living condition from only trying to sustain themselves and their families to trading for profits. From the livelihood that is unique to the locality, after being under Siam and going through the French colonization, the livelihood of the people within the society also changed to be more appropriate to the circumstance. The idea of materialism that was adopted by the people in 
power had caused people to be more opened to be more welcome of other cultures and had caused the traditional culture to be changed or altered. After being under the socialist system, the items used within the royal ceremonies along with many beliefs either disappeared or changed their forms. These are some of the reasons for the changes in the souvenirs which goes along with the research by Singyabuth (2008) that had stated that Luang Prabang has its unique physicality in opening up new social and cultural space for people from different ethnicities since the ancestral time. In the past, Luang Prabang was the queen amongst the kingdom of Laos. At present, it is the main city of Luang Prabang province, a cultural World Heritage site under UNESCO, one of the major tourism site for Laos nad one of the main destination for tourism around the world. This goes in line with a research by Sriruksa (2015) who had stated that Luang Prabang still maintains its norms and traditions, as well as its uniqueness of traditional Lao ancient sites. Luang Prabang had gone through 3 major developments: the kingdom era where the country was ruled over by a king, the first stage of strict socialism nad the new idea era where the Lao state had created the relationship with the global capitalist system under its new context. The government had designated and built Luang Prabang to become a cultural World Heritage site as well as a city aimed for cultural tourism on the global scale. Luang Prabang is therefore, under the idea and the operation of three main power: Lao state, the World Heritage office and the tourism industry for the consumption of the past. These main powers contribute to the physical changes in the society and rituals which had led to the adaptation of the old rituals to meet the new kind of norms and to create new social memories for the people of Luang Prabang at that time.

From the background of the souvenirs in Luang Prabang, one can see the characteristics of the changes in different eras which had created a new form of change from the society with low civilization to one with a high civilization. This development and change were done through three following steps slow revolution and changes, revolutionize, improving old traditions nad rapid revolutionize of the whole system which resulted in erasing the old ways andreplaced them with newer technologies. This is similar to Nathalang (2015)'s statement saying that science and technology became the main strategy in developing products. However, in the past decades when the world entered into the era where there is more limitation in the use of natural resources and where technology created equality for all productions, souvenirs can now be produced to replicate certain characteristics of different eras and to address the need of the consumers.

The background of souvenirs in Luang Prabang revealed the connection between the tradition and the way of life of people in Luang Prabang. Changes happen according to new eras but at a slow pace. The beginning was the creation of the community and the continuous evolution until it became the cultural way, the beautiful way of life, a mold that holds all the components of the society, the culture and the tradition. Similar, to Chaipratoom (2001) who stated that culture and tradition is an important capital that can be developed to help people generate their income which is in line with this research and the new idea policy in opening up the country. Additionally, this also causes the cultural legacy such as textile to be produced as products for the tourists that keep flooding into the country and will lead Luang Prabang into the World Heritage era. This is being done step by step while each step is the development from the previous ones. This is similar to Vanivong (2009)'s research who had integrated the ancient mural paintings into the souvenirs to the tourists who came to visit Luang Prabang; such as textiles and mulberry products. The is in line with the research by Theerayuth (2014) which talked about the development and the changes in handicraft products, the beliefs and culture related to the products, their uses, the materials and the production, the creativity and the beauty of the handicraft products which had changed to its purpose towards tourism and trades. The technology and the new designs under the context of the World Heritage site of the souvenirs within the research includes products such as textiles, paper products, silverware products and basketry products. These products were shifted from being the items that people use in their daily lives to become the products for tourism purposes in this context of the World Heritage city.

\section{CONCLUSION}

The background of souvenirs in Luang Prabang from the pre-Lan Xang kingdom era to the World Heritage era can be explained as follows: souvenirs were domestic products made by the local people of Lao based on the context of the area of Luang Prabang. They also reflect the relationship to the norms and traditions as well as the way of life on the people in the city with the differences on the form, the materials, the beauty and their usages such as silverware, textiles, basketry products, carved wood, mulberry paper items and mural paintings. These products had been changed according to each era and the situations that occurred and became part of the exchange or used as tributes such as textiles with gold thread lining and jewelry made from silver. The products are now being produced in larger amounts to be traded. The materials such as silver beads, silk and cotton are now being imported from other cities instead of using local materials. Some of the products that were only used within the palace or religious ceremony are now being 
produced for sold such as textiles, silver jewelry that were only used in the palace or for religious ceremonies, carved wooden Buddha images, paper that were used for wrapping, making umbrellas, making notepads for monks or making lanterns, paintings with Buddhist stories and basketry products are now being turned into products aimed at the tourists coming to this World Heritage city. Some of the more complicated patterns are now simplified with additional colors and more modern patterns.

\section{RECOMMENDATIONS}

General recommendation: There should be suggestions signs made for the tourists or even the local people, about the souvenirs which are considered the traditional handicraft products of Luang Prabang to provide the knowledge and bringing pride and value to the products. There should be an office that considers the benefits and the downsides of duplicating souvenirs for tourism, the advantages over both the producers and the consumers in order to create a mutual understanding.

Recommendations for future research: There should be a study on the local wisdom related to each kind of souvenirs in Luang Prabang in order to better understand the ideology and the capacity of the wisdom of the producers and the factors related to the creation of the souvenirs. There should be a study on the souvenirs in other areas of Lao PDR such as Vientiane and Champasak in order to make comparisons and better understand the context of each area.

\section{REFERENCES}

Bodhisan, S., 2015. Lao history. Master Thesis, Text Production Fund, Khon Kaen University, Khon Kaen, Thailand.

Chaipratoom, J., 2001. Commoditization of the process of textile culture in luang prabang under PDRS new economic mechanism. P.hD Thesis, Graduate School, Khon Kaen University, Khon Kaen, Thailand.
Kasetsart University, 2000. Laotian Thai-English dictionary. Kasetsart University, Bangkok, Thailand.

Masuhara, Y., 2003. Economic System of the Lan Xang Kingdom (Laos) in the 16-17th Centuries: From Regional Trading City to Semi Port Polity. Pikkanet Printing Center Ltd., Bangkok, Thailand,.

Mettarikanon, D., 2012. Multi-dimensional history of lao PDR. Ancient City, Thai Ban Mai, Thailand.

Nathalang, S., 2015. Thai folklore in a changing world. Princess Maha Chakri Sirindhorn Anthropology Centre, Bangkok, Thailand.

Silrattana, P., 2001. Souvenir. O.S. Printing House, Bangkok, Thailand,.

Singyabuth, S., 2008. Luang prabang, the world cultural heritage: Memories of royal city, ritual space and globalization. Ph.D. Thesis, Graduate School, Mahasarakham University, Talat, Thailand.

Sriruksa, K., 2015. Naga arts of luang prabang: Forms of symbolic ideology and definition of city as world heritage. Ph.D. Thesis, Graduate School, Khon Kaen University, Khon Kaen, Thailand.

Srisamang, S., 2002. List in Lao Kings in Chronology. 2nd Edn., St. Joseph Communications, Toronto, Canada,.

Srisontisuk, S., 2001. Case Study on Society and Culture: Concept, Methodology and Theories. Amarin Printing Book Publishers Company, Thailand,.

Theerayuth, P., 2014. Luang Prabang handicraft product: Development and change in world Heritage City. Ph.D Thesis, Khon Kaen University, Khon Kaen, Thailand.

Vanivong, K., 2009. A study of mural art in luang prabang, lao PDR for the applied design and development of souvenir products. Master Thesis, Graduate School of Ubon, Ratchathani University, Jaeramair, Thailand.

Weeravong, M.S., 1997. History of Lao PDR (Translator by S. Premjit). 3rd Edn., Bangkok Art and Culture Centre, Bangkok, Thailand,. 